\title{
Use of Information and Communication Technologies for Sustainable Agricultural Development among Rural Farmers in Ekiti State Nigeria
}

\author{
Adekunmi A. 0. \\ Department of Agricultural Economics \\ And Extension Services, Ekiti State University \\ Ado - Ekiti, Nigeria. \\ Awoyemi A. 0. \\ Department of Agricultural Economics \\ And Extension Services, Ekiti State University \\ Ado - Ekiti, Nigeria.
}

\begin{abstract}
The study assessed the use of Information and Communication Technologies (ICTs) for sustainable agricultural development among rural farmers of Ekiti State, Nigeria. The specific objectives were to describe the socio-economic characteristics of rural farmers; determine the availability and accessibility of various ICTs to farmers study; determine the perception of farmers concerning ICTs, ascertain the types and frequency of use of ICTs in receiving agricultural information; evaluate the level of satisfaction with regard to the information received through various ICTs; and identify some constraints militating against the use of ICTs in the study area. The study was carried out in Ekiti State where one hundred and twenty farmers were randomly selected from the ADP zones in the states. Data were collected from rural farmers using structured interview schedule and were subjected to descriptive and inferential statistics. The results of the analysis revealed that the average age of the farmers was 42.6 years. Majority (94.2\%) of the respondents were males who were married and $(93.3 \%)$ are Christians. The major ICTs commonly used among the farmers were GSM mobile phone, radio, television and newspapers. Rural farmers in the area had a favourable perception about ICTs. Respondents in the area considered radio and television to be the most relevant sources of agricultural information to them. Results of the data also shows that age $(r=0.138, p \leq 0.01)$ and Cosmo politeness $\left(. r^{2}=0.045 ; P, 0.05\right)$ of farmers have significant relationship with the use of ICTS for sustainable agricultural deployment. It was recommended that local language should be used to disseminate agricultural information via ICTS to rural farmers.
\end{abstract}

Keywords: Information and Communication Technology in Ekiti State, Sustainable Agriculture, development among- Rural farmers

\section{INTRODUCTION}

Knowledge production in the society is accelerating and knowledge improves with rapid development in information and communication technology (World Bank, 1998). World Bank (2000) and Little, S., P. Qunitas and T. Ray (2002) also asserted that information and communication technology is a significant factor of economics production and growth. Information and communication (ICT) is defined as the basket of technologies, which assist or support the storage and dissemination of data or information Singh Krishna M. and Kumar, Abhay and Singh, R.K.P., (2015). Waren (2010) notes that ICTs include; television, radio, telephone, video, voice information system, fax and computer. This means that with the use of 
ICTs tools mentioned above, knowledge, data and information can be disseminated to the users (farmers).As confirmed by Opata, P.; Nweze J.; and Rahman, M. (2011). ICTs are a powerful tool for spreading crucial information. Aker (2010) also affirms that ICT is necessary for accessing required information and knowledge. With the use of ICTs, farmers can reach or communicate and get information from their counterparts, researchers and scientists all over the world with ease. ICTs are a real source of information and knowledge for farmers and that it reduces distances, among different communities of the world Herselmen (2003). In developing countries like Nigeria, there is a need to improve our agricultural practices, link with other farmers and marketers in the world, access current information on issues like climate change and better way to mitigate or adapt to its effect and access new innovative technologies. Also through the use of ICTs, farmers can gain knowledge on better ways of averting risk and make good decision on the use of scarce resources. Man and Saridya (2009) asserts that the agricultural sector in Nigeria is facing many challenges in obtaining new information about market price, new agriculture innovation, weather updates and climate change issue. To ensure food security in Nigeria, farmers' production and productivity need to be increased. FAO (2009) reports that the growing global population is expected to rise to 90 billion by 2050 and to feed the expected population; the food production has to be increased to $70 \%$.Therefore, agricultural sector cannot afford to continue with crude methods of farming. Subsistence farmers in Nigeria need information on how to enhance their productivities, and be fully fortified with knowledge to overcome problems militating against increase production. The use of ICTs will bring new information resources and new open communication channels for rural communities which will enhance their productivities. The constant use of various ICTs by rural farmers will go a long way in sustaining the development as far as agriculture is concerned This is in line with Ogbona and Agwu (2013) who asserted that ICTs when available to farmers improve the amount and quality on information either indirectly through producers, associations, extension workers and the like or through broadcast radio information and mobile phone messaging. From the foregoing the study tried to assess the extent of the use of ICTs for sustainable agricultural development among the rural farmers in Ekiti State, Nigeria. Hence the following research questions. What are the types of ICTs available in the study area?; How frequently do farmers use the available ICTs in sourcing agricultural information?; How satisfied are the respondents in the use of available ICTs? How do farmers perceive the use of ICTs in receiving agricultural information? and what are the perceived constraints militating against the use of ICTs?

The main objective of the study is to assess the use of information and communication technologies (ICTs) for sustainable agricultural development among rural farmers in Ekiti State, Nigeria.

The specific objectives are to:

- describe the socio-economic characteristics of the rural farmers

- ascertain the type and frequency of use of ICTs in receiving agricultural information;

- evaluate farmers level of satisfaction with regards to the information received through various ICTs;

- determine the perception of farmers in the use of ICTs for sustainable agricultural development; and

- identify perceived constraint militating against farmers use of ICTs 


\section{HYPOTHESIS}

There is no significant relationship between socio-economic characteristics of the rural farmers and the use of ICTs for agricultural development

\section{METHODOLOGY}

The study was conducted in Ekiti State, Nigeria. The State has sixteen local government areas (LGAs). Ekiti State is located within the longitude $4^{0} 4^{\prime}$ and $5^{0} 45^{\prime}$ east of Greenwich meridian and on latitude $7^{015}$ north of the equator. The State is bounded in the north by Kwara and Kogi states and in the west by Osun state and in the south by Ondo state. The population of Ekiti State is about 2,212,609 males and 1,717,603 females (NPC, 2006). The temperature in the State ranges between 21 and $28^{\circ} \mathrm{C}$ with high humidity. About 70 percent of the populations are farmers which basically makes her an agrarian society. Ekiti State has three agricultural development programme Zones (ADPs) which falls under two distinguished vegetative zones which are the rainforest zone and the derived savannah zone. A multi-stage sampling procedure was employed for the sample selection. At the first stage, all the three ADPs zones were employed in the selection of the sample i.e. Isan North, Ikere South and Aramoko central zones. At the second stage, one quarter $(1 / 4)$ of the blocks from ach zone were proportionately selected for the study i.e. one block from Isan North, and Ikere south and two blocks from Aramoko central zones. At the third stage three communities were randomly chosen from each block selected making a total of twelve (12) communities. At the final stage, ten (10) farmers were randomly selected from each of the communities sampled. A total of one hundred and twenty respondents were selected for the study. Data were collected employing a wellstructured interview schedule. Data gathered were analyzed using descriptive statistics such as percentages mean frequency counts and inferential statistics such as correlation analysis (r).

\section{Socio-economic characteristic of the respondents}

\section{RESULTS AND DISCUSSION}

Data in Table 1 shows that the majority (75.0\%) of the respondents were between 41 and 60 years. The average age of the respondents was 42.6 years. The result implies that majority of the respondents were still economically active and could contribute effectively to the sustenance of agricultural development through the procurement of necessary ICTs materials for agricultural information. The findings further show that $94.2 \%$ of the respondents were males while $5.8 \%$ of them were females. This shows that men were actively involved in farming than women in the study area. The marital status of the respondents shows that the majority (93.3\%) of the respondents were married. Data in Table 1further revealed that 93.3\% of the respondents were Christians and only $6.7 \%$ of them were Muslims. The respondents' distribution based on the level of education shows that only $6.7 \%$ had no formal education while others received formal education ranging from adult education (5.8\%), primary education (35.0\%), secondary education (40.0\%) and tertiary education (12.5\%). This implies that respondents could read and write. This finding is in line with Salau and Saingbe (2006) who posited that more education and awareness is required to improve the level of utilization of ICTs.

However, if they are properly taught on how to use various ICTs to collect information on agricultural development, with the little education they had, it will help them. The distribution of the respondents based on their annual income revealed that $46.7 \%$ earned less than $\# 200$, 000 per annum, while 37.5 percent earned between $\$ 200,000$ and $\$ 400,000$ per annum. About 11.7 percent earned between $\$ 401,000$ and $\$ 600,000$ while just 4.1 percent earned about $\mathrm{N} 600,000$. (48.3\%) of the respondents engaged in crop cultivation and $30.0 \%$ of them engaged in poultry production. Only few (11.7\%) of them were involved in livestock farming 
and fishery (10.0\%). This reveals that the respondents engaged themselves in different farming enterprises

Table 1: Distribution of respondents based on socio-economic characteristics

\begin{tabular}{|c|c|c|}
\hline Variables & Percentage & $\begin{array}{c}\operatorname{Mean}(\mathrm{n}= \\
120)\end{array}$ \\
\hline \multicolumn{3}{|l|}{ Age } \\
\hline $20-39$ & 17.5 & \\
\hline $40-59$ & 75.0 & $X=42.56$ \\
\hline $60-79$ & 7.5 & \\
\hline 80 and above & 0.0 & \\
\hline \multicolumn{3}{|l|}{ Sex } \\
\hline Male & 94.2 & \\
\hline Female & 5.8 & \\
\hline \multicolumn{3}{|l|}{ Marital status } \\
\hline Married & 93.3 & \\
\hline Single & 4.2 & \\
\hline Divorced & 2.5 & \\
\hline \multicolumn{3}{|l|}{ Religion } \\
\hline Christianity & 93.3 & \\
\hline Islam & 6.7 & \\
\hline \multicolumn{3}{|l|}{ Educational status } \\
\hline No formal education & 6.7 & \\
\hline Adult education & 5.8 & \\
\hline Primary education & 35.0 & \\
\hline Secondary education & 40.0 & \\
\hline Tertiary education & 12.5 & \\
\hline \multicolumn{3}{|l|}{ Farming activities } \\
\hline Crop cultivation & 48.3 & \\
\hline Livestock farming (i.e. cattle, goat, etc.) & 11.7 & \\
\hline Fishery & 10.0 & \\
\hline Poultry & 30.0 & \\
\hline \multicolumn{3}{|l|}{ Annual income $(\mathrm{N})$ per annum) } \\
\hline$<200,000$ & 46.7 & \\
\hline $200,000-400,000$ & 37.5 & \\
\hline $401,000-600,000$ & 11.7 & \\
\hline$>\mathrm{N} 600,000$ & 4.1 & \\
\hline
\end{tabular}

\section{Types and Frequency of Use of ICTs}

Data in Table 2 shows the distribution of respondents according to the types of ICTs available for agricultural information in the study area. The result shows that the respondents in varying percentages attested to the fact that the following ICTs were available; radio $(100.0 \%)$, mobile phone (93.3\%), television (80.8\%), and computer (23.3\%). Only $17.5 \%$ of them indicated that video coverage was available. However, $76.7 \%$ of them indicated that computer, internets, emails, e-books and facsimile (FAX) and flash drive were not available to all the respondents. Also, $(98.3 \%),(89.2 \%)$ and $(86.7 \%)$ of the respondents indicated that CD, Newspapers and projector respectively were not available for use by the respondents. 
Table 2: Distribution of respondents according to the types of ICTs available

\begin{tabular}{lcc}
\hline Types of ICTs & Available (\%) & Not Available (\%) \\
\hline Mobile phone/GSM & 93.3 & 6.7 \\
Computer & 23.3 & 76.7 \\
Television & 80.8 & 19.2 \\
Radio & 100.0 & 0.0 \\
Internets & 0.0 & 100.0 \\
e-mail & 0.0 & 100.0 \\
e-books & 0.0 & 100.0 \\
video coverage & 17.5 & 82.5 \\
facsimile (FAX) & 0.0 & 100.0 \\
CD & 1.7 & 98.3 \\
Flash drive & 0.0 & 100.0 \\
Newspapers & 10.8 & 89.2 \\
Projector & 13.3 & 86.7 \\
\hline
\end{tabular}

\section{Source: Field Survey, 2015}

\section{Distribution of Respondents based on Frequency of Use of ICTs}

Table 3 shows the distribution of respondents according to the frequency of use of ICTs. The majority (93.3\%), (80.8\%) and (96.7\%) of the respondents noted that they always used mobile phone, television and radio respectively to receive information. All (100.0\%) the respondents indicated that they never used internets, e-mail, e-books, facsimile (fax) and flash drive for receiving any information. The majority of the respondents $(91.7 \%),(86.7 \%)$ of the respondents indicated that they were never used newspapers and projector respectively to receive information. This might be due to the fact that these ICTs items were not available to them and not been commonly used by them in receiving agricultural information

Table 3: Distribution of respondents according to the frequency of use of ICTs

\begin{tabular}{lcccc}
\hline \multicolumn{1}{c}{ Types of ICTs } & $\mathbf{1}$ & $\mathbf{2}$ & $\mathbf{3}$ & $\mathbf{4}$ \\
\hline Mobile phone/GMS & $-(0.0)$ & $4(3.3)$ & $4(3.3)$ & $112(93.3)$ \\
Computer & $102(85.0)$ & $3(2.5)$ & $15(12.5)$ & $0(0.0)$ \\
Television & $-(0.0)$ & $12(10.0)$ & $11(9.1)$ & $97(80.8)$ \\
Radio & $-(0.0)$ & $-(0.0)$ & $4(3.3)$ & $116(96.7)$ \\
Internets & $-(100.0)$ & $-(0.0)$ & $-(0.0)$ & $-(0.0)$ \\
e-mail & $120(100.0)$ & $-(0.0)$ & $-(0.0)$ & $-(0.0)$ \\
e-books & $120(100.0)$ & $-(0.0)$ & $-(0.0)$ & $-(0.0)$ \\
Video coverage & $99(82.5)$ & $1613.3)$ & $5(4.2)$ & -0.0 \\
Facsimile (FAX) & $120(100.0)$ & $-(0.0)$ & $-(0.0)$ & $-(0.0)$ \\
CD & $118(98.3)$ & $-(0.0)$ & $(-0.0)$ & $-(0.0)$ \\
Flash drive & $120(100.0)$ & $-(0.0)$ & $-(0.0)$ & $-(0.0)$ \\
Newspapers & $110(91.7)$ & $04(3.3)$ & $04(3.3)$ & $-(0.0)$ \\
Projector & $104(86.7)$ & $06(5.0)$ & $06(5.0)$ & $-(0.0)$ \\
\hline
\end{tabular}

\section{Source: Field Survey, 2015}

Percentage in parenthesis

Key: 4 -Always, 3- Occasionally, 2-Rarely, 1-Never 


\section{Farmers' Level of Satisfaction in the Use of ICTs}

The results in Table 4 show how satisfied respondents were in the use of ICTs for receiving agricultural information. High satisfaction were recorded in the use of Television (69.2\%), radio $(76.7 \%)$ for receiving information for sustainable agriculture. This was probably so because modernization has made radio and television to be commonly found in most rural households. This is in tandem with Achariya(2010) who reported that there is high possession of television in this era, and even in slums. Also Omosa (2001) reported that radio was obviously one of the fastest, most powerful and in most countries, the most popular means of communication with the rural farmers. He further said that radio defeats obstacles faced by extension workers or any other agencies responsible for the dissemination of various agricultural information. On the other hand, no satisfaction was derived from the use of newspapers as noted by $64.2 \%,(72.5 \%)$, e-mails, CD $(80.8 \%), 82.5 \%$, computer, projector (83.3\%), (95.8\%), internets, (100.0\%), facsimile (FAX) (100.0\%), flash drives and e- books $100.0 \%$ of the respondents. This might be due to the respondents' low level of education. Slightly above half $(56.7 \%)$ of the respondents did not derive any satisfaction from the use of mobile phone. This was probably so because mobile phones were used as one of the social media to relate with one another apart from gathering information on agriculture. In other words, mobile phones are used to collect general information other than agricultural information

Table 4: Distribution of respondents based on the level of satisfaction with information received from the use of ICTs

\begin{tabular}{lllll}
\hline \multicolumn{1}{c}{ ICTs } & $\mathbf{4}$ & $\mathbf{3}$ & $\mathbf{2}$ & $\mathbf{1}$ \\
\hline Mobile phone/GSM & $23(19.2)$ & $14(11.7)$ & $15(12.5)$ & $68(56.7)$ \\
Computer & $09(7.5)$ & $02(1.7)$ & $10(8.3)$ & $79(82.5)$ \\
Television & $83(69.2)$ & $21(17.5)$ & $09(7.5)$ & $01(5.8)$ \\
Radio & $92(76.7)$ & $14(11.7)$ & $09(7.5)$ & $05(4.2)$ \\
Internets & $(0.0)$ & $03(2.5)$ & $02(1.7)$ & $115(95.8)$ \\
e-mails & $49(40.8)$ & $04(3.3)$ & $08(6.7)$ & $87(72.5)$ \\
e-books & $(0.0)$ & $(0.0)$ & $00(0.0)$ & $120(100.0)$ \\
video coverage & $(0.0)$ & $33(27.5)$ & $10(8.3)$ & $28(23.3)$ \\
facsimile (FAX) & $(0.0)$ & $(0.0)$ & $(0.0)$ & $120(100.0)$ \\
CD & $(0.0)$ & $(0.0)$ & $23(19.2)$ & $97(80.8)$ \\
Flash drives & $(0.0)$ & $(0.0)$ & $(0.0)$ & $120(100.0)$ \\
Newspapers & $(0.0)$ & $23(19.2)$ & $20(16.7)$ & $77(64.2)$ \\
Projector & $(0.0)$ & $(0.0)$ & $08(6.7)$ & $112(83.3)$ \\
& & & & \\
\hline
\end{tabular}

Percentage is parenthesis

Source: Field Survey, 2015

Key: 4 - Highly satisfied, 3 - Satisfied, 2 - Fairly satisfied, 1 - Not at all

Multiple responses were recorded

\section{Farmers' Perception on the Use of ICTs}

Table 5 shows the distribution of respondents according to their perception on the use of ICTs for gathering agricultural information. Majority strongly agreed on some perception statements about ICTs. About 76.7 percent of the respondents strongly agreed that ICTs usage facilitated dissemination of agricultural information to them while 63.3 percent strongly agreed that the use of ICTs helped in boosting their agricultural productivities. Other perception statements strongly agreed to are agricultural information spread rapidly when 
ICTs are in use (84.2\%), the use of ICTs broadens their knowledge on modern farming techniques as strongly agreed to by 81.7 percent of respondents. ICTs enhance practical demonstrations of innovations as submitted by 62.5 percent while 71.7 percent of the respondents submitted that ICTs are time-saving devices. The findings show that the respondents have favourable perceptions towards the use of ICTs for sustainable agricultural development in the study (65.8\%), close to half of the respondents (46.7\%), strongly disagreed that ICTs are the only means through which agricultural innovations can be collected gathered; ICTs are cheaper compared to other means and information gathering through the use of ICTs can be simple to understand respective

Table 5: Perception of respondents on the use of ICTs

\begin{tabular}{|c|c|c|c|c|c|}
\hline Perception statements & SA & $\mathbf{A}$ & D & SD & Total \\
\hline $\begin{array}{l}\text { 1. ICTs facilitate dissemination } \\
\text { of agricultural information }\end{array}$ & $92(76.7)$ & $24(20.0)$ & $4(3.3)$ & $-((0.0)$ & 120 \\
\hline 2. The use of ICTs is the only & $24(20.0)$ & $06(5.0)$ & $09(7.5)$ & $81(67.5)$ & \\
\hline
\end{tabular}

means through which

agricultural information could reach the farmers.

3. The use of ICTs boosts my productivity.

4. Agricultural information spread faster with the use of ICTs.

5. The use of ICTs broadens our knowledge on modern farming

6. Information dissemination through ICTs can be simple to understand.

7. ICTs enhance practical demonstrations of innovation

8. ICTs are cheaper than other means collecting or gathering agricultural innovation.

9. ICTs are cheaper than other mans of gathering agricultural innovation

10. ICTs re time-saving devices

$\begin{array}{lllc}76(63.3) & 41(34.2) & 02(1.7) & 01(0.8) \\ 101(84.2) & 18(15.0) & 01(0.8) & -(0.0) \\ 98(81.7) & 21(17.5) & 01(0.8) & -(0.0) \\ 38(31.7) & 22(18.3) & 04(3.3) & 56(46.7) \\ 75(62.5) & 42(35.0) & 03(2.5) & 0(0.0) \\ 14(11.7) & 03(2.5) & 24(20.0) & 79(65.8) \\ 82(68.3) & 26(21.7) & 07(5.8) & 05(4.2) \\ 86(71.7) & 30(25.0) & 03(2.5) & 01(0.8)\end{array}$

Source: Field Survey, 2015

Multiple responses recorded. Percentage in parenthesis

Key: SA -Strongly agreed, A -Agreed, D -Disagreed, SD - Strongly Disagreed

\section{Perceived Constraints to ICT use}

The results of data in Table 6 explain different constraints being encountered by the rural farmers. More than half of the respondents (61.7\%) indicated that prices of ICTs were unaffordable to them. This findings correlate with the finding of Jorge (2002) who asserted that even when infrastructure is available, affordable, access is a concern in most developing countries. Fors and Moreno (2002) further stated that ICTs equipment are expensive and unaffordable to the majority of the inhabitants of developing countries, thereby cutting down the number of people who are able to use the technology. Majority of the respondents (72.5\%) submitted that maintenance was a problem to them, while 48.3 percent saw complex nature of 
most ICTs as a problem. Internet access cost was a problem as argued by 93.3 percent of the respondents. Insufficient internet band width and difficulty in repairs which is similar to maintenance cost were problems of 81.7 percent and 40.0 percent of the respondents respectively. Other constraints were lack of content $(20.0 \%)$, lack of interest (22.5\%), and items not readily available (30.0\%), not relevant as adjudged by 24.2 percent of the respondents and lack of required skills (35.0\%). These findings confirm the result of the study conducted by Agwu et al (2008) and Olutayo (2010) that these problems tend to make the use of ICTs among the youths difficult. These problems were making the use of ICTs for sustainable agricultural development among rural farmers very much difficult.

Table 6: Distribution of respondents based on constraints faced in the use of ICTs

\begin{tabular}{lcc}
\hline \multicolumn{1}{c}{ Constraints } & Frequency & Percentage (\%) \\
\hline Price of ICTs & 74 & 61.7 \\
Maintenance cost & 87 & 72.5 \\
Complexity & 58 & 48.3 \\
Internet access cost & 112 & 93.3 \\
Insufficient internet band width & 98 & 81.7 \\
Difficulty of repairs & 48 & 40.0 \\
Lack of related content & 24 & 20.0 \\
Lack of interest & 27 & 22.5 \\
Items, not readily available & 36 & 30.0 \\
Not relevance & 29 & 24.2 \\
Lack of required skill & 42 & 35.0 \\
\hline
\end{tabular}

\section{HYPOTHESIS}

The results of the analysis on Table 7 shows that there was significant relationship between the age $(r=0.138)$, cosmopoliteness $(r=0.045)$, educational level $(r=0.371)$ and farming activities $(r=0.309)$ at $\mathrm{P} \leq 0.01$ and the use of ICTs for sustainable agriculture. The implications of these findings are that the older the respondents, the more capable they will be in handling or operating some of these ICTs. The more they traveled outside their villages and the more educated they are, the more knowledgeable they are in the handling and utilization of these ICTs for sustainable agriculture. Farming activities was also significantly related to the use of ICTs. This implies that the more of the various farm enterprises they involved in, the more likelihood the use of more of the ICTs for sustainable agricultural development. Household size was however not significantly related to the use of ICTs with $(r=0.042, p \leq 0.01)$. This means that household size did not correlate with the use of ICTs.

Table 7: Correlation Analysis showing the relationship between socio-economic characteristics of the rural farmers and the use of ICTs for agricultural development

\begin{tabular}{lc}
\hline \multicolumn{1}{c}{ Variables } & r-value \\
\hline Age & 0.138 \\
Cosmopoliteness & 0.445 \\
Educational level & 0.371 \\
House hold size & -0.042 \\
Farming activities & 0.309 \\
\hline
\end{tabular}

Source: Field Survey, 2015

Chi-square $\left(\mathrm{x}^{2}\right)$ analysis was also employed to test the significance of some socio-economic variables in Table 8 . The result shows that sex $\left(x^{2}=1.22, p<0.05\right)$, marital status $\left(x^{2}=0.29, p<\right.$ $0.05)$ and religion $\left(x^{2}=9.98, p<0.05\right)$ were not significantly related to the use of ICTs. 
Table 8: Relationships between some socio-economic nominal variables and the use of ICTs.

\begin{tabular}{lcc}
\hline \multicolumn{1}{c}{ Variables } & $\mathbf{x}^{2}$ Value & Df \\
\hline Sex & 1.22 & 1 \\
Marital status & 0.29 & 2 \\
Religion & 9.98 & 2 \\
\hline
\end{tabular}

Source: Field Survey 2015

\section{CONCLUSIONS AND RECOMMENDATION}

Radio, television and mobile phone were widely utilized while e-books, e-mails, flash drives and internets were poorly or not used at all. Inadequate or poor infrastructure prevented the respondents from harnessing ICTs. Age, distance travelled, educational status and farming activities had significant relationship with the use of ICTs for sustainable agriculture. Therefore, there should be provision of social infrastructure, especially uninterrupted power supply and local language should be the common medium of expression to rural farmers while disseminating agricultural information. via ICTs to the rural farmers.

\section{References}

Agwu, E.; Uche-Mba, U.C. and Akinagbe, O.M. (2008). Use of information communication technologies (ICTs) among researchers' extension worker and farmers in Abia and Enugu States: Implication for national extension policy on ICTs, Journal of Agricultural Extension, 12 (1): 37.

Aker, J.C. (2010). “Dial 'A' for Agriculture. Using information and Communication Technology for Agricultural Extension in Developing Countries. "Toft University, Economic Department and Gletcher School, Medford MA 02155 .

Evans, T.P. and Ekpia, H.R. (2009). Regimes of information land use, management and policy. The information society, 25 (5) $328-3413$.

Fawole O. and Olajide, B. (2012). Awareness and use of information communication technologies by farmers in Oyo State, Nigeria. Journal Agricultural and Food Information. 13(4) 326 - 337.

Fors, E.M. and Moreno, A. (2002). The benefits and obstacles of implementing ICTs strategies for development from a bottom-up approach. Aslib proceedings, 54 (3): 192 - 206.

Herselman, M.E. (2003). ICT in rural areas in south Africa. Various case studies. In proceedings of informing science information technology education Joint Conference. Pg.945 - 955.

ICT is necessary for accessing required information and knowledge. Akor 2010.

Little.S., P. Qunitas and T. Ray(2002) Managing Knowledge. An essential Reader. sage London

K.M. Singh, Abhay Kumar and R.K.P. Sigh. Role of Information and Communication Technology in Indian Aquaculture. An overview. July 26, 2015.

Man, N. and Sadiya, I. (2009). Off-arm employment participation among Paddy farmers in the Indian Agricultural Development Authority and Kamasin Semarak Granay Arces of Malysia. Asia - Pacific Development Journal. 16 (2), $141-153$.

Ogbona O.I. and AgwuA,E. Availablity levelof use , importance and constraints to utization of infor,mation commun9ication technologies by farmers in Enugu State, Nigeria. Direct Reseaerch Jouuunal of Agriculture and Food Science VOL; (4)pp. 44-48. Available online at http://direct. researchpublisher.org/drjafs.

Omosa . E. (2001).The use and Application of various communication channels at local and International levels: Kenya: Forest Action Network

Olutayo, O.B. (2010). The challenges of changing trends in the development and use of information and internet web communication technologies for veterinary medicine education in Nigeria. http://knowledge.cta.intl.

Opata, P.; Nweze J.; and Rahman, M. (2011). The place of information and communication technology in promoting agro-based enterprise in third world countries. Journal of Agricultural Technologies. 7 (2) 207 - 214.

Opera, U.N. (2008). Agricultural information source used by farmers in Imo State, Nigeria. Information Development, 24 (4), 289 - 295. 
Salau, E.S. and Saingbe, N.D. (2006). Access and utilization of information and communication technologies (ICTs) Among agricultural researchers and extension workers in selected institutions in Nasarawa State of Nigeria. http/patnsukjournal.net/vol4 No2/pl.pdf.pp1-6

Singh Krishna M. and Kumar, Abhay and Singh, R.K.P. Roole of ICTs in Indian Agriculture (February 26, 2015). Available at SSRN. http:issm.com/abstract $=2570710$ R.K.P. -RAM KEWAL Prased Sij. Singh.

Warren, M.F. (2002). Adoption of ICT in agricultural management in the United Kingdom. The intra rural digital divide. Agricultural Economy 48 (1) 1 - 8. When information and knowledge are well improved agriculture and rural development.

World Bank. (1998) World Development Report 1998/1999. Knowledge for Development. Oxford University Press New York.

World Bank. (2000) World Development Report 2000/2001. Attacking Poverty Oxford University Press New York 